\title{
Glimepiride as Add-on Therapy in Type 2 Diabetic Patients with Metformin Monotherapy: A Real-Life Study from Egypt
}

\author{
YEHIA GHANEM, M.D. \\ The Department of Internal Medicine, Unit of Diabetes, Faculty of Medicine, Alexandria University, Alexandria, Egypt
}

\begin{abstract}
Background: Adding glimepiride to metformin monotherapy was reported to improve the glycemic status of patients with type 2 diabetes mellitus (T2DM), with tolerable safety profile.
\end{abstract}

Aim of Work: The present real-life study aimed to investigate the safety and effectiveness of glimepiride add-on therapy in poorly controlled T2DM patients with metformin monotherapy.

Patients and Methods: In the present prospective study, we included 1050 poorly controlled T2DM patients from Egypt, and for whom the investigators decided to prescribe glimepiride in addition to metformin. Glimepiride was added to patients uncontrolled on metformin monotherapy for at least three months despite reaching the maximally tolerated dose. Regimen doses were decided by the investigators to reflect the in-practice approach. We followed the included patients for at three months and safety outcomes were measured throughout the study period.

Results: After three months of treatment, the mean HbAlc level decreased by $1.54 \%$ (95\% CI: -1.61 to $-1.46 \%)$, with a mean percentage reduction of $16.3 \%(p<0.001)$. In addition, $31.7 \%$ of the included patients achieved the targeted $\mathrm{HbA} 1 \mathrm{c}$ level $<7 \%$. The total number of adverse events was 15 adverse events occurred in 11 patients. Ten episodes of non-serious hypoglycemia were recorded.

Conclusion: The present real-life study confirms the efficacy of glimepiride add-on therapy to metformin monotherapy among poorly controlled T2DM patients from Egypt. Moreover, glimepiride/metformin regimen exhibits welltolerable safety profile.

Key Words: Glimepiride - Metformin - HbAl c-Hypoglycemia $-T 2 D M$.

\section{Introduction}

TYPE 2 diabetes mellitus (T2DM) is one of the most common causes of morbidity and mortality worldwide, with major health and financial conse-

Correspondence to: Dr. Yehia Ghanem, The Department of Internal Medicine, Unit of Diabetes, Faculty of Medicine, Alexandria University, Alexandria, Egypt quences [1]. Poorly controlled T2DM patients may experience a wide variety of micro-and macrovascular complications that merely affect every single organ in the body; however, early and proper control of glycemic status can minimize these consequences $[2,3]$. The main lines of management of T2DM consist of lifestyle modifications and oral antidiabetics (OADs). OADs are proposed to reduce the chronic hyperglycemic status of T2DM patients through reducing insulin resistance, enhancing insulin secretion, and increasing glucagonlike-peptide-1 secretion [4]. However, a growing body of evidence shows that the administration of single OAD fails to properly control the glycemic status of patients with T2DM $[5,6]$. Moreover, the need to reach the maximum tolerated dose with mono-therapy, in order to achieve the targeted glycemic control, was linked to increased risk of serious hypoglycemia [3] . Recently, It was recommended that OADs should be administrated in combination regimens with a complementary mechanism to achieve the targeted glycemic control in patients with poorly controlled T2DM [5].

Glimepiride is a third-generation sulfonylurea that stimulates the pancreatic B cells to enhance insulin secretion with significant improvement in both first- and second-phase insulin secretion [7] In addition, glimepiride showed a lower incidence of hypoglycemic events compared to other sulfonylureas [8]. It has been suggested that adding glimepiride to metformin-based therapy potentially leads to more improvement in glycemic control, as metformin improves hepatic and peripheral tissue insulin resistance while glimepiride enhances insulin secretion [9]. The use of a glimepiride/ metformin combination may improve patients' compliance compared with instructing the patient to multiple pills, as well $[\mathbf{1 0 , 1 1 ]}$. In addition to its cost-effectiveness, glimepiride/metformin combination was reported to minimize the side effects 
that may result from instructing T2DM patients to a high-dose of OAD mono-therapy [11] .

According to the Diabetes Atlas 2014, Egypt is considered the 8 th country in the International Diabetes Federation's top 10 countries for adults (20-70 years) with diabetes. Egypt has around 7.5 million patients with diabetes; where the diabetes comparative prevalence according to the WHO standard is $16.62 \%$ [12]. Despite the worldwide consensus recommendations, we lack the published literature from Egypt that assess the real-life efficacy of glimepiride/metformin combination in the management of patients with T2DM. In this regards, the present prospective study aimed to evaluate the safety and efficacy of prescribing glimepiride to Egyptian patients with poorly controlled T2DM on metformin monotherapy.

\section{Patients and Methods}

In the present observational prospective study, patients in 76 active sites from different governorates in Egypt between November 2013 and May 2016. Were included if they met the following criteria: (1) Adult patients ( $\geq 21$ years) with poorly controlled T2DM despite being on the maximum tolerated dose, (2) Patients who received metformin monotherapy only, and (3) Patients whose physicians decided to prescribe glimepiride as add-on therapy to metformin. We excluded patients with severe hepatic or renal disorders, and patients with reported hypersensitivity to glimepiride or metformin.

The physicians were randomly selected according to their specialties. Each participating physician was asked to include consecutive patients during the recruitment period, starting from the initiation date at each site, to limit bias related to physicianled patients selection. For every participating patient, the following data were collected: Demographic characteristics, medical history, and baseline $\mathrm{HbA} 1 \mathrm{c}$ levels. The included participants were then followed for three months and $\mathrm{HbA} 1 \mathrm{c}$ levels were measured at the end of the follow-up. Safety outcomes were measured throughout the course of treatment. All adverse events, whether related to the glimepiride/metformin combination or not, were recorded from the first day of therapeutic administration. The seriousness of the adverse events and corrective interventions were also monitored.

The primary endpoints of the present study were the mean change in $\mathrm{HbA} 1 \mathrm{c}$ after three months of treatment with glimepiride/metformin combination. Secondary endpoints included: The percentage of patients who reached the target $\mathrm{HbA} 1 \mathrm{c} \leq 7 \%$ after three months of treatment; the mean change in fasting plasma glucose (FPG), postprandial plasma glucose (PPG), and body weight $(\mathrm{Kg})$ at the end of the study; and the incidence of adverse events.

Data entry, verification, and validation were carried out using standard computer software. A double-entry method was used to ensure that the data were transferred accurately from the case report forms to the database. Data were analyzed using the software, Statistical Package for Social Science (SPSS Inc. Released 2009, PASW Statistics for Windows, Version 18.0: SPSS Inc., Chicago, Illinois, USA), then processed and tabulated. Frequency distribution with its percentage and descriptive statistics with mean and standard deviation were calculated. Chi-square, $t$-test, correlations were done whenever needed. $p$-values of less than 0.05 were considered significant.

The study was conducted in full accordance with the guidelines for good clinical practice and the Declaration of Helsinki, and data for each patient were collected only after obtaining that patient's signed written data release forms.

\section{Results}

Initially, we screened a total of 1050 patients from Egypt with poorly controlled T2DM, for whom the investigators decided to add glimepiride to metformin monotherapy. Out of those 1050 initially enrolled patients, 12 patients did not meet the eligibility criteria, while 83 patients were excluded for loss to follow-up. Thus the efficacy analysis included only 955 patients. The dosing regimens and the need to add insulin or other medications were left to the investigators to experience the real-life practice.

The majority of subjects $(60.8 \%)$ had T2DM since 1-5 years. The mean age of the included patients was $48.2 \pm 11.4$ years with an average weight of $88.2 \pm 12.9 \mathrm{~kg}$. Slightly more than half (53.9\%) (f the patients) were males. The baseline systolic blood pressure was $130.4 \pm 15 \mathrm{mmHg}$, diastolic blood pressure $82.5 \pm 8$, and heart rate of $79.5 \pm 7.9$ beat/minute. Almost $80 \%$ of patients reported a positive family history of diabetes, and $41.6 \%$ of the patients had medical or surgical complications rather than diabetes. The majority of patients were instructed to $\leq 2000 \mathrm{mg}$ daily of metformin. After the baseline visit, all patients were instructed to glimepiride, and most of the patients were prescribed to $\leq 4 \mathrm{~g}$ daily. Notably, a total of $10(9.6 \%)$ patients needed add-on basal 
insulin, $3(0.3 \%)$ patients needed rapid-acting insulin, and $6(0.6 \%)$ patients needed other OADs (Table 1).

Table (1): Baseline characteristics of the included patients.

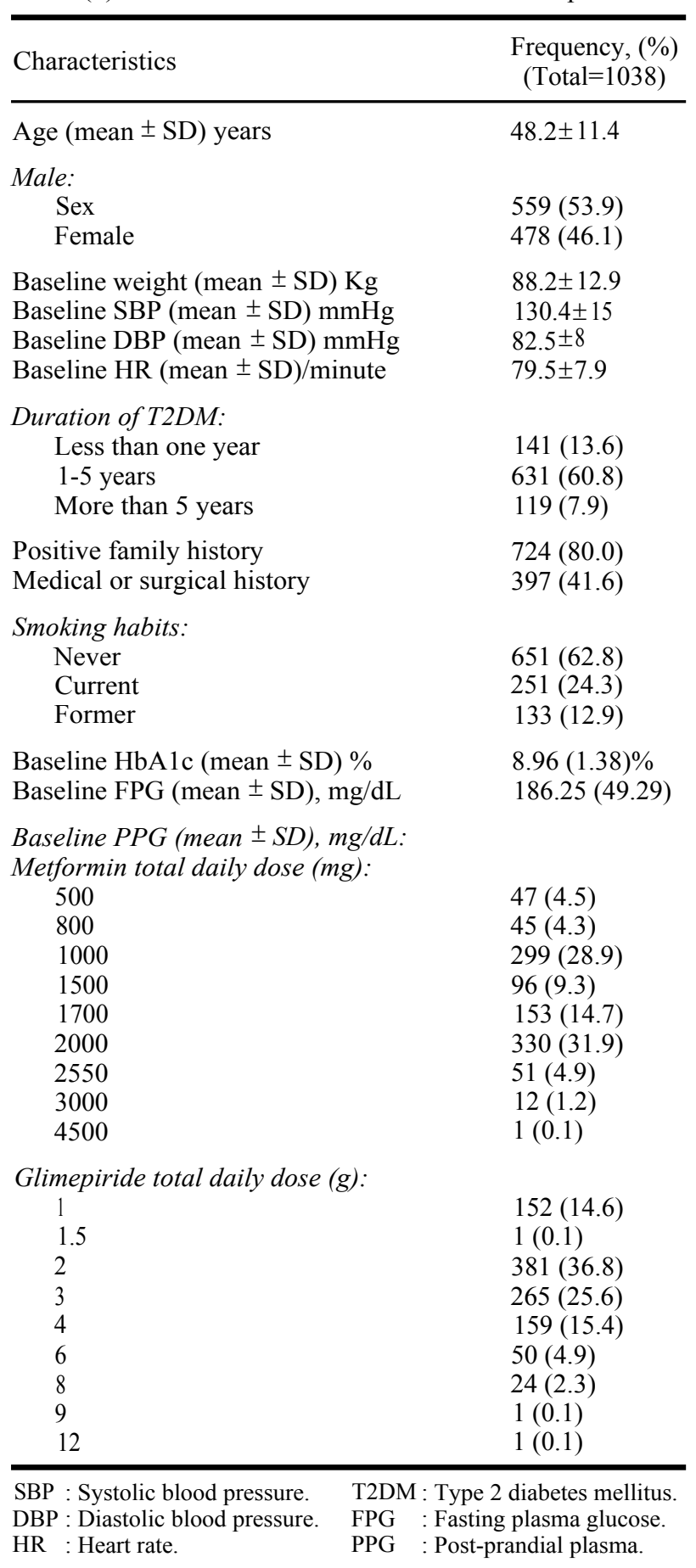

After three months of treatment, the HBA1 c decreased significantly from $8.96 \pm 1.38 \%$ to $7.4 \pm$ $1.1 \%$. The mean change in HBA $1 \mathrm{c}$ level at the end of follow-up was $-1.54 \%$ (95\% CI: -1.61 to $1.46 \%$ ), and the mean relative reduction was $16.3 \%(p<0.001)$. At the final visit, $31.7 \%$ of patients achieved the targeted $\mathrm{HbA} 1 \mathrm{c}$ level $\leq 7 \%$
Fig. (1). The mean change in FPG level was $56.8 \mathrm{mg} / \mathrm{dL}(95 \% \mathrm{CI}: 59.75$ to $53.85 \mathrm{mg} / \mathrm{dL})$ at month three, while the mean relative reduction was $27.9 \%(p<0.001)$. The PPG level decreased significantly by a mean of $90.4 \mathrm{mg} / \mathrm{dL}(95 \% \mathrm{CI}$ :

94.69 to $86.10 \mathrm{mg} / \mathrm{dL}$ ) at the end of study period $(p<0.001)$. While the mean change in body weight was $0.87 \mathrm{~kg}$ (95\% CI: 1.11 to $-0.63 \mathrm{~kg})(p<0.001)$. (Table 2).

Throughout the study period, 11 patients $(1.06 \%)$ experienced a total of 15 adverse events. Mild hypoglycemia occurred in six subjects with no incidence of severe hypoglycemia. Hyperglycemia occurred in two cases, both were mild and were not considered as treatment-related. The incidence of adverse events throughout the study period are shown in Table (3).

Table (2): Mean change in primary and secondary outcomes at the end of study.

\begin{tabular}{|c|c|c|c|}
\hline Endpoints & Baseline & Month 3 & $p$-value \\
\hline $\begin{array}{l}\text { HbAlc level: } \\
\text { Mean (SD) } \\
\text { Mean change } \\
\text { from baseline } \\
\text { (SD) }\end{array}$ & $\begin{array}{l}8.96(1.38) \\
-1.54(95 \% \mathrm{CI}\end{array}$ & $\begin{array}{l}7.43(1.07) \\
:-1.61 \text { to }-1.46)\end{array}$ & $<0.001$ \\
\hline $\begin{array}{l}\text { FPG level, } \mathrm{mg} / \mathrm{dL} \text { : } \\
\text { Mean, 95\% CI } \\
\text { Mean change } \\
\text { from baseline } \\
\text { (SD) }\end{array}$ & $\begin{array}{c}186.25 \text { (49.29) } \\
-56.8 \text { (95\% CI: }\end{array}$ & $\begin{array}{c}129.54(34.59) \\
-59.75 \text { to }-53.85)\end{array}$ & $<0.001$ \\
\hline $\begin{array}{l}P P G \text { level, } \mathrm{mg} / \mathrm{dL} \text { : } \\
\text { Mean, } 95 \% \mathrm{CI} \\
\text { Mean change } \\
\text { from baseline } \\
\text { (SD) }\end{array}$ & $\begin{array}{l}266.88(74.3) \\
-90.4(95 \% \mathrm{CI}\end{array}$ & $\begin{array}{c}176.53(51.02) \\
-94.69 \text { to }-86.10)\end{array}$ & $<0.001$ \\
\hline $\begin{array}{l}\text { Body Weight Kg: } \\
\text { Mean, 95\% CI } \\
\text { Mean change } \\
\text { from baseline } \\
\text { (SD) }\end{array}$ & $\begin{array}{l}87.92(12.57) \\
-0.87 \text { (95\% CI: }\end{array}$ & $\begin{array}{r}87.09(12.08) \\
-1.11 \text { to }-0.63)\end{array}$ & $<0.001$ \\
\hline
\end{tabular}

FPG : Fasting plasma glucose.

PPG : Post-prandial plasma.

Table (3): Reported acute adverse events among the included patients.

\begin{tabular}{lc}
\hline Adverse events & $\begin{array}{c}\text { Frequency (\%) } \\
\text { (Total=1038) }\end{array}$ \\
\hline Hypoglycemia & $10(1.4)$ \\
Hyperglycemia & $2(0.2)$ \\
GIT Upsets & $2(0.2)$ \\
Pregnancy & $1(0.1)$ \\
\hline
\end{tabular}

*Every subject may have more than one AEs/ADRs. GIT: Gastrointestinal system. 


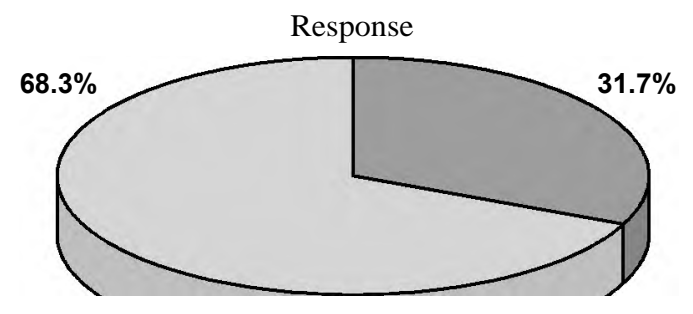

Fig. (1): The percentage of patients who responded to treatment after 3 months.

\section{Discussion}

Glimepiride and metformin are one of the most commonly prescribed OADs worldwide. Metformin improves insulin resistance in peripheral tissue and hepatic cells, making it widely recommended as the first OAD of choice, particularly for newly diagnosed patients with T2DM. On the other hand, glimepiride is a third generation Sulfonylurea that enhances insulin secretion through stimulating pancreatic B cells. Glimepiride, in comparison to other sulfonylureas, can selectively target the pancreatic ATP-sensitive potassium channel leading to an improvement in glucose transport [13]. When Metformin mono-therapy fails to control the hyperglycemic status of T2DM patients, glimepiride can be prescribed as add-on therapy. In the present real-life study, $31.7 \%$ of patients, who were prescribed to glimepiride/metformin free combination, achieved the targeted $\mathrm{HbA} 1 \mathrm{c} \leq 7 \%$ after three months of treatment. In addition, the mean $\mathrm{HbA} 1 \mathrm{c}$ level showed a statistically significant reduction by $1.54 \%$. In addition, FPG, PPG, and body weight decreased significantly at the end of the study. Glimepiride/metformin free combination exhibited a tolerable safety profile as well.

According to 2012 ADA/EASD position statement, adding a second agent to metformin is expected to reduce $\mathrm{HbA} 1 \mathrm{c}$ level by $1.5 \%$ in patients with poorly controlled T2DM [14]. In the present study, we observed a significant reduction in $\mathrm{HbAlc}$ by $1.54 \%$ after the prescription of glimepiride/ metformin free combination. In concordance with our results, a growing evidence of the published literature reported the clinically significant efficacy of glimepiride/metformin combination. Pareek and colleagues conducted a prospective study to evaluate the efficacy of glimepiride/metformin free combination on 93 patients with uncontrolled T2DM, they reported that $\mathrm{HbA} 1 \mathrm{c}$ decreased significantly after three months of treatment (mean change $=-0.7 \pm 1.55$ ); a similar significant reduction was observed in FPG and PPG levels [9]. GonzálezOrtiz and colleagues, a study on 76 patients with uncontrolled T2DM, reported that a total of $44.6 \%$ of the patients in glimepiride/metformin combination group achieved the targeted $\mathrm{HbA} 1 \mathrm{c}$ level after 12 months of treatment [15]

Glimepiride/metformin fixed-dose combination was reported to be effective as well. Kim and colleagues [16] conducted a randomized controlled trial on 209 patients with T2DM, they concluded that glimepiride/metformin fixed-dose combination therapy was more effective in glycemic control than metformin up-titration, with similar safety profile. The targeted $\mathrm{HbA} 1 \mathrm{c}$ level was achieved in $74.7 \%$ of the patients (versus $46.6 \%$ patients in metformin group), with a significantly greater reduction in mean $\mathrm{HbA} 1 \mathrm{c}$ level at the end of treatment. Another report showed that the fixed dose combination of glimepiride/metformin achieved $3 \%$ reduction in mean $\mathrm{HbA} 1 \mathrm{c}$ level after three months, while half of the patients showed a HbA1 c reduction of at least $1 \%$ [17].

Hypoglycemia is a major concern when using sulfonylureas. However, glimepiride was reported to be associated with lower rates of severe hypoglycemia than other sulfonylureas, which may be attributed to its potentially controllable effect on insulin secretion [18]. Pareek and colleagues [19] reported an incidence rate of $2 \%$ of symptomatic hypoglycemia. Another report showed a higher proportion of hypoglycemic events were observed in the glibenclamide group compared to glimepiride group (28.9\% vs. $17 \%$, respectively) [15]. The Korean study by Kim and colleagues [16] reported a high incidence of hypoglycemia in glimepiride/ metformin combination group (41\%), while metformin group showed an incidence of (5\%). However, in the present study, hypoglycemia occurred in $6(0.5 \%)$ patients only, with no reported severe hypoglycemic event.

In this observational study conducted in Egypt, the addition of glimepiride to metformin monotherapy in patients with uncontrolled T2DM was associated with an improved glycemic control and was well-tolerated.

\section{Acknowledgments:}

The study was sponsored and funded by Sanofi, which played no role in analyzing or interpreting the data. A statistical analysis was provided by RAY Contract Research Organization. Editorial support was provided by Ahmed Elgebaly, Reham Elgarhy and Fady Adel of RAY Contract Research Organization and was funded by Sanofi.

\section{Authors' COI:}

The author has no conflicts of interest to declare. 


\section{References}

1- TURNER R.: Effect of intensive blood-glucose control with metformin on complications in overweight patients with type 2 diabetes (UKPDS 34). Lancet, 352: 854-865. doi: 10.1016/S0140-6736(98)07037-8, 1998.

2- TURNER R.: Intensive blood-glucose control with sulphonylureas or insulin compared with conventional treatment and risk of complications in patients with type 2 diabetes (UKPDS 33). Lancet 352: 837-53. doi: 10.1016/S01406736(98)07019-6, 1998.

3- HOLMAN R.R., PAUL S.K., BETHEL M.A., et al.: 10year follow-up of intensive glucose control in type 2 diabetes. N. Engl. J. Med., 359: 1577-89. doi: 10.1056/ NEJMoa0806470, 2008.

4- TURNER R.C., CULL C.A., FRIGHI V. and HOLMAN R.R.: Glycemic control with diet, sulfonylurea, metformin, or insulin in patients with type 2 diabetes mellitus: progressive requirement for multiple therapies (UKPDS 49). UK Prospective Diabetes Study (UKPDS) Group. JAMA, 281: 2005-12. doi: 10.1017/CB O9781107415324.004, 1999.

5- HERMANN L.S., SCHERSTEN B., BITZÉN P.O., et al.: Therapeutic comparison of metformin and sulfonylurea, alone and in various combinations: A double-blind controlled study. Diabetes Care, 17: 1100-9. doi: 10.2337/ diacare.17.10.1100, 1994.

6- WRIGHT A.D., CULL C.A., HOLMAN R.R. and TURNER R.C.: UKPDS 28: A randomized trial of efficacy of early addition of metformin in sulfonylurea-treated type 2 diabetes. Diabetes Care, 21: 87-92. doi: 10.2337/diacare. 21.1.87, 1998.

7- ROSENKRANZ B.: Pharmacokinetic basis for the safety of glimepiride in risk groups of NIDDM patients. Horm. Metab. Res., 28: 434-9. doi: 10.1055/s-2007-979833, 1996.

8- DRAEGER E.: Clinical profile of glimepiride. Diabetes Res. Clin. Pract, 28: S139-S146. doi: 10.1016/01688227(95)01072-L, 1995.

9- PAREEK A., CHANDURKAR N.B., SALKAR H.R., et al.: Evaluation of efficacy and tolerability of glimepiride and metformin combination: A multicentric study in patients with type- 2 diabetes mellitus, uncontrolled on monotherapy with sulfonylurea or metformin. Am. J. Ther., 17: 559-565. doi: 1 0.1 097/MJT.0b0 13 e3181 ff7c63, 2010.

10- ZHU H., ZHU S., ZHANG X., et al.: Comparative efficacy of glimepiride and metformin in monotherapy of type 2 diabetes mellitus: Meta-analysis of randomized controlled trials. Diabetol. Metab. Syndr, 5: 70. doi: 10.1186/17585996-5-70, 2013.

11- MELIKIAN C., WHITE T.J., VANDERPLAS A., et al.: Adherence to oral antidiabetic therapy in a managed care organization: A comparison of monotherapy, combination therapy, and fixed-dose combination therapy. Clin. Ther., 24: 460-7. doi: 10.1016/S0149-2918(02)85047-0, 2002.

12- FEDERATION I.D.: IDF Diabetes Atlas Sixth edition. idf.org 1-2. doi: 2-930229-80-2, 2014.

13- GEISEN K., VÉGH A., KRAUSE E. and PAPP J.G.: Cardiovascular effects of conventional sulfonylureas and glimepiride. Horm. Metab. Res., 28: 496-507. doi: 10.1055/s-2007-979841, 1996.

14- INZUCCHI S.E., BERGENSTAL R.M., BUSE J.B., et al.: Management of hyperglycemia in type 2 diabetes: A patient-centered approach: Position statement of the American Diabetes Association (ADA) and the European Association for the Study of Diabetes (EASD). Diabetes Care, 35: 1364-79. doi: 10.2337/dc12-0413, 2012.

15- GONZÁLEZ-ORTIZ M., GUERRERO-ROMERO J.F., VIOLANTE-ORTIZ R., et al.: Efficacy of glimepiride/ metformin combination versus glibenclamide/metformin in patients with uncontrolled type 2 diabetes mellitus. J. Diabetes Complications, 23: 376-9. doi: 10.1016/ j.jdiacomp.2008.09.002, 2009.

16- KIM H. SOON, KIM D. MAN, CHA B. SOO, et al.: Efficacy of glimepiride/metformin fixed-dose combination vs metformin uptitration in type 2 diabetic patients inadequately controlled on low-dose metformin monotherapy: A randomized, open label, parallel group, multicenter study in Korea. J. Diabetes Investig., 5: 701-8. doi: 10.1111/jdi.12201, 2014

17- GONZÁLEZ-ORTIZ M., MARTÍNEZ-ABUNDIS E., GUERRERO ROMERO C.F., et al.: Eficacia y seguridad de la terapia hipoglucemiante oral combinada de glimepirida más metformina en una sola forma farmacéutica en pacientes con diabetes mellitus tipo $2 \mathrm{y}$ falla secundaria a monoterapia con glibenclamida. Rev. Investig. Clin., 56: 327-33, 2004.

18- HOLSTEIN A., PLASCHKE A. and EGBERTS E.H.: Lower incidence of severe hypoglycaemia in patients with type 2 diabetes treated with glimepiride versus glibenclamide. Diabetes Metab. Res. Rev., 17: 467-73. doi: 10.1002/ dmrr.235, 2001.

19- PAREEK A., CHANDURKAR N.B., SALKAR H.R., et al.: Evaluation of Efficacy and Tolerability of Glimepiride and Metformin Combination. Am. J. Ther., 20: 41-7. doi: 10.1097/MJT.0b013e3181ff7c63, 2013. 


\section{جليميبريد كعلاج إضافى لمرض السكر من النوع الثانى على متفورمين وحده: دراسة واقعية من مصر الفوعرانر}

الخلفية: تم الإبلاغ عن أن إضافة عقار جليمييريد إلى العلاج الأحادى بعقار ميتفودمين يؤدى إلى تحسين حالة سكر الدم المرضى الذين يعانون من مرض السكرى من النوع (Y)، مع تحقيق ملف أمان الإن مقبول.

الهدف من العمل: هدفت الدراسة الفعلية القائمة إلى التحقق من أمان وفعالية العلاج الإضافى بعقار جليمييريد فى المرضى الذين يقارئ يعانون

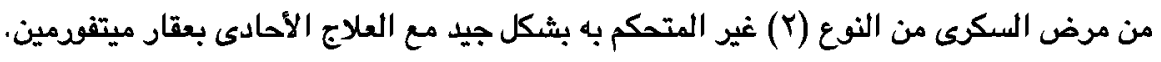

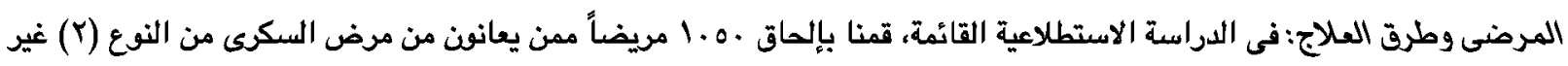

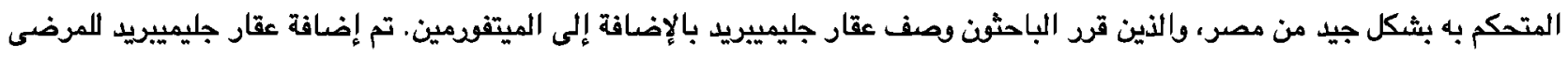

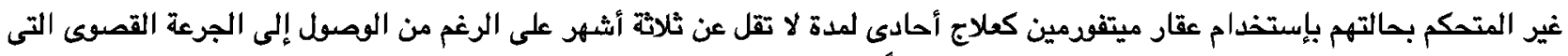

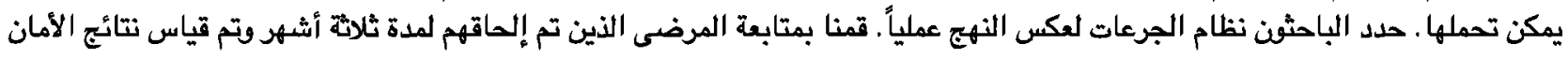
على مدار فترة الدراسة.

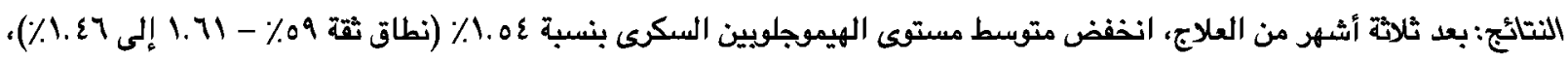

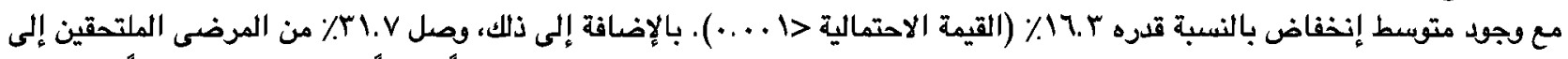

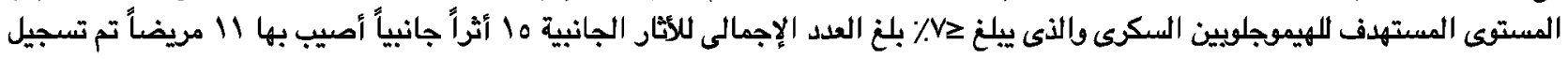
. الات من حلوث نقص غير خطير بسكر الدمبين.

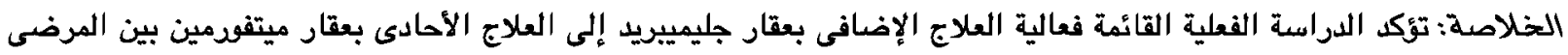

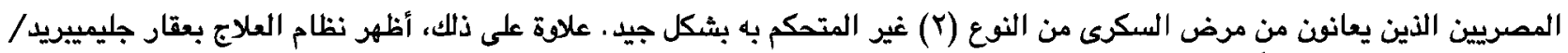
ميتفودمين ملف أمان مقبولاً بشكل جيد الفرين. 